Esta revista forma parte del acervo de la Biblioteca Jurídica Virtual del Instituto de Investigaciones Jurídicas de la UNAM

\title{
MEXICAN TELECOM REFORM: PRIVATE INTEREST FIRST?
}

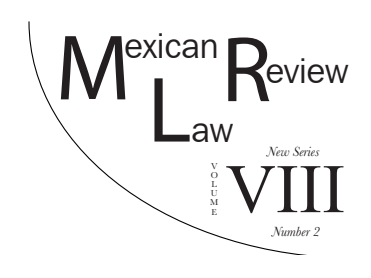

\author{
Clara Luz ÁLvAREZ*
}

\begin{abstract}
Telecommunications reform, one of the pillars of President Enrique Peña Nieto's highly-publicized structural reforms, was enacted to recognize as human rights access to: (i) information and communications technology; and (ii) broadcasting and telecommunications services, including broadband and the Internet. The reform also gave the Mexican government the authority to sanction or even split up companies engaged in monopolistic practices, and to establish ad hoc restrictions to minimize undue market advantages for dominant industry players - defined as companies that capture 50 percent market share measured by number of users/audience, capacity or network infrastructure. This article explores several aspects of this new legislation, including regulatory agencies; media and plurality; audience and users' rights; restrictions to minimize market manipulation; mergers; data retention and geo-localization; and access for persons with disabilities. It also examines various aspects of the legislative process, as well as some broader implications of the new law.
\end{abstract}

KEY WoRDs: Telecommunications, broadcasting, audience, mergers, antitrust, plurality, competition.

Resumen. La reforma de telecomunicaciones en México fue uno de los pilares de las llamadas reformas estructurales, cuyo objetivo fue reconocer a nivel constitucional el derecho de acceso a los servicios de telecomunicaciones y radiodifusión, los derechos de la audiencia, asi como fijar límites a los grandes grupos corporativos de telecomunicaciones y radiodifusión. Este artículo presenta los aspectos principales de la nueva ley mexicana de telecomunicaciones (el regu-

\footnotetext{
* Álvarez, Clara Luz is member of the Mexican National Researchers System (level II) and researcher at the Universidad Panamericana. She received the National Journalism Award for spreading democratic culture for its program Código Democracia at the Congress Channel (2014). Clara Luz is author of the books Derecho de las Telecomunicaciones (3a. ed., 2014) and Internety Derechos Fundamentales (2011), and coordinator of the book Telecomunicaciones y Tecnologías de la Información (2012). She was rapporteur for the International Telecommunications Union's study group of ICT accessibility for persons with disabilities (2006-2011), and Commissioner for the Mexican Telecommunications Commission (Cofetel). claraluzalvarez@gmail.com//claraluzalvarez.org.
} 
Esta revista forma parte del acervo de la Biblioteca Jurídica Virtual del Instituto de Investigaciones Jurídicas de la UNAM

lador, pluralidad y medios, derechos de las audiencias y usuarios, la preponderancia, medidas contra los dominantes, concentraciones, conservación de datos y geolocalización, usuarios con discapacidad), los aspectos relevantes del proceso legislative y el análisis del proceso legislativo.

PALABRAS CLAVE: telecomunicaciones, radiodifusión, audiencia, concentraciones, competencia económica, pluralidad, competencia.

TABLE OF CONTENTS

I. BACKGROUND

II. Major Reform without Debate ............................................... 50

III. Telecommunications in the Gonstitution .............................. 52

IV. INDEPENDENT REGULATOR? .................................................... 54

V. Media and Plurality ..................................................................... 56

VI. Audience and User Rights .................................................... 60

VII. Public or Private Interests First? .............................................. 65

VIII. Human Rights Concerns ........................................................ 70

IX. Positive Aspects.................................................................... 72

X. Final Remarks ................................................................... 73

\section{BACKGROUND}

Following the 1910 revolution, Mexico's economy was developed by monopolistic interests that operated on the local, regional and national levels. The telecom sector was no exception. ${ }^{1}$ Since capital formation and economies of scale were so vital in developing a functional infrastructure, the government deemed competition as against the public interest. ${ }^{2}$ Licenses were granted on a discretionary basis pursuant to loyalty both to the government and (most importantly) the PRI (Partido Revolucionario Institucional), the political party that ruled Mexico for over 70 years. ${ }^{3}$ Without loyalty, no applicant was able to obtain a broadcasting license.

1 Example in telecommunications can be found on the Ley de Vías Generales de Comunicación (1940). Also see Clara Luz Alvarez, Derecho de las Telecomunicaciones 391 (Fundalex and Posgrado de Derecho de la UNAM, 2013).

2 InfoDev, Forms of Market Failure, ICT Regulation Toolkit, (Nov. 7, 2014, 12.44 PM) http://www.ictregulationtoolkit.org/en/toolkit/notes/practicenote/2609.

3 Partido Revolucionario Institucional, México, el PRI y sus Cifras (Aug. 23, 2014, 1.30 PM) http://pri.org.mx/TransformandoaMexico/MexicoPRI/MexicoysusCifras.aspx. 
The Broadcasting Law was enacted in 1960 to regulate free-to-air radio and TV, including digital content. Although this law was amended several times during the $20^{\text {th }}$ century, the most significant amendment was the socalled Ley Televisa $a^{4}$ enacted in 2006. In a case filed by a group of senators against it, ${ }^{5}$ Mexico's Supreme Court later declared several major parts of this law to be unconstitutional. ${ }^{6}$

The 1990s was characterized by privatizations and economic liberalization. The Mexican government privatized the public telecom monopoly (Telmex, 1990), ${ }^{7}$ a public TV broadcasting network (Imevisión - Canal 7 and 13, 1993), and the satellite monopoly (Satmex, 1997). ${ }^{8}$ The Telecommunications Law enacted in 1995 helped open the telecom sector to competition, including the creation of a regulator (Cofetel, 1996-2013). ${ }^{9}$ Increased competition was supposed to improve the quality of services, increase access and lower prices.

Although nearly two decades have passed since the supposed opening of the Mexican telecom market, the sector is still dominated by a few powerful players:

- Fix telephony $=$ América Móvil (Telmex): $67.7 \%{ }^{10}$

- Fix data $=$ América Móvil (Telmex): 66.9\%. ${ }^{11}$

4 This amendment was known as Ley Televisa because of evidence that Grupo Televisa played a major role in both drafting the amendment and the legislative process.

5 An action challenging the constitutionality of a law (acción de inconstitucionalidad) may be filed by at least $1 / 3$ of the senators or deputies. Senators from the three major political parties (PRI, Partido Acción Nacional and Partido de la Revolución Democrática) signed the lawsuit against the Ley Televisa.

6 Suprema Corte de Justicia de la Nación [S.C.J.N] [Supreme Court], Sentencia relativa a la Acción de Inconstitucionalidad 26/2006 promovida por Senadores integrantes de la Quincuagésima Novena Legislatura del Congreso de la Unión, en contra del propio Congreso y del Presidente Constitucional de los Estados Unidos Mexicanos, asi como los votos formulados por el señor Ministro Genaro David Góngora Pimentel, Pleno, Diario Oficial de la Federación [D.O.], 20 de agosto de 2007 (Mex.).

7 Álvarez, supra note 1, at 396-400.

8 Álvarez, supra note 1, at 407-409.

9 The regulator was named Comisión Federal de Telecomunicaciones. See Clara Luz Alvarez, Órganos reguladores de telecomunicaciones, año IV, número 10, México, Praxis de la fusticia Fiscal y Administrativa del Tribunal Federal de Fusticia Fiscal y Administrativa, 1,34 (2012) (Nov. 12, 2014, 12:48 PM), http://www.tfjfa.gob.mx/investigaciones/pdf/organosreguladores.pdf.

10 Instituto Federal de Telecomunicaciones, Resolución mediante la cual el Pleno del Instituto Federal de Telecomunicaciones determina al grupo de interés económico del que forman parte América Móvil, S.A.B. de C.V., Teléfonos de México, S.A.B. de C.V., Teléfonos del Noroeste, S.A. de C.V., Radiomóvil Dipsa, S.A. B. de C.V., Grupo Carso, S.A.B. de C.V., y Grupo Financiero lnbursa, S.A.B. de C.V., como agente económico preponderante en el sector de telecomunicaciones y le impone las medidas necesarias ara evitar que se afecte la competencia y la libre concurrencia, Pleno, V Sesión Extraordinaria 2014, P/IFT/060314/76, p. 91 (Nov. 12, 2014, 12:51 PM) http://apps.ift.org.mx/publicdata/P_IFT_EXT_060314_76_ Version_Publica_Hoja.pdf, 6 de marzo de 2014 (Mex).

11 Id. 
Esta revista forma parte del acervo de la Biblioteca Jurídica Virtual del Instituto de Investigaciones Jurídicas de la UNAM

- Mobile telephony $=$ América Móvil (Telcel): $70.1 \%{ }^{12}$

- Mobile data and internet = América Móvil $\left(\right.$ Telcel): $62 \%{ }^{13}$

- Pay TV = Grupo Televisa: approx. $53.7 \% .^{14}$

- Free-to-air TV = Grupo Televisa: 70\% $(2012)^{15}$ average share of transmissions computed from the beginning of the transmission to the end of it. ${ }^{16}$

\section{Major Reform without Debate}

One day after Enrique Peña Nieto's inauguration as President of Mexico (2012), the Pact for Mexico between the new administration and all major Mexican political parties was announced. ${ }^{17}$ The Pact for Mexico was based on an ambitious policy agenda, including major reforms in both telecommunications and broadcasting.

In 2013, President Peña Nieto submitted several proposals for constitutional amendments that involved education, energy, tax, finance, telecom

$12 I d$.

13 Id.

14 See Ernesto Piedras and Carlos Hernández, TV de paga y servicios convergentes 2012, The Competitive Intelligence Unit, (May 30, 2014, 11:30 AM), http://www.the-ciu.net/ nwsltr/119_1Distro.html.

15 Instituto Federal de Telecomunicaciones, Resolución mediante la cual el Pleno del Instituto Federal de Telecomunicaciones determina al grupo de interés económico del que forman parte Grupo Televisa S.A. B., Canales de Televisión Populares, S.A. de C.V., Radio Televisión, S.A. de C.V., Radiotelevisora de México Norte, S.A. de C.V., T.V. de los Mochis, S.A. de C.V., Teleimagen del Noroeste, S.A. de C.V., Televimex. S.A. de C.V., Televisión de Puebla, S.A. de C.V., Televisora de Mexicali, S.A. de C.V., Televisora de Navojoa, S.A., Televisora de Occidente, S.A. de C.V., Televisora Peninsular, S.A. de C.V., Mario Enríquez Mayans Concha, Televisión La Paz, S.A., Televisión de la Frontera, S.A., Pedro Luis Fitzmaurice Meneses, Telemisión, S.A. de C.V., Comunicación del Sureste, S.A. de C.V., José de Jesús Partida Villanueva, Hilda Graciela Rivera Flores, Roberto Casimiro González Treviño, TV Diez Durango, S.A. de C.V., Televisora de Durango, S.A. de C.V., Corporación Tapatía de Televisión, S.A. de C.V., Televisión de Michoacán, S.A. de C.V., Fosé Humberto y Loucille, Martinez Morales, Canal 13 de Michoacán, S.A. de C.V., Televisora XHBO, S.A. de C.V, TV Ocho, S.A. de C.V., Televisora Potosina, S.A. de C.V., TV de Culiacán, S.A. de C.V., Televisión del Pacifico, S.A. de C.V., Tele-Emisoras del Sureste, S.A. de C.V., Televisión de Tabasco, S.A. y Romana Esparza González, como agente económico preponderante en el sector radiodifusión y le impone las medidas necesarias para evitar que se afecte la competencia y la libre concurrencia, Pleno, V Sesión Extraordinaria 2014, P/IFT/060314/77, p. 408 (Nov. 11, 2014, 12:56 PM), http://apps.ift.org.mx/publicdata/P_ IFT_EXT_060314_77.pdf, 6 de marzo de 2014 (Mex.).

${ }_{16}$ Please note that Grupo Televisa and Grupo TV Azteca (its direct competitor in free to air TV) jointly hold $94 \%$ of the commercial TV licenses in the Mexican Republic. At the same time both corporations have jointly owned the holding company of Iusacell that provides mobile telephony, until Televisa decided to sell its 50\% back to Grupo TV Azteca (September 2014) and Grupo TV Azteca sold 100\% of Iusacell's holding to AT\&T (November 2014).

17 Presidencia de la República, Pacto por México, (Aug. 14, 2014, 3:10 PM) http://www. presidencia.gob.mx/wp-content/uploads/2012/12/Pacto-Por-México-TODOS-losacuerdos.pdf, 2 de diciembre de 2012 (Mex.). 
and antitrust. In Mexico, these bills are presented to either the Chamber of Deputies or to the Senate, and then such Chamber will be deemed the origin Chamber. The bill is then analyzed by one or more committees, and a report is prepared for debate before being put up for vote. The report is then submitted to the Chamber of origin for further debate. If approved, it goes to the reviewing Chamber which follows the same procedure. While ordinary legal amendments require a majority of votes to pass, constitutional amendments require 2/3 approval by both Chambers and a majority of State legislatures. ${ }^{18}$

At no point during the legislative process to amend the Constitution or enact new regulations was there any meaningful debate in either the Senate or Chamber of Deputies.

When discussion was opened to the floor, legislators opposing any part of the proposed changes faced no questions from other lawmakers. ${ }^{19}$

18 Constitución Política de los Estados Unidos Mexicanos [Const.], as amended, Diario Oficial de la Federación [D.O.], 5 de febrero de 1917 (Mex.), articles 71, 72 and 135.

19 Analysis of congressional sessions involving constitutional and legal reforms show a clear lack of debate. The senators or deputies took the floor to present their positions without any real questioning from the other legislators. See (1) Presentación, discusión y votación en el Pleno de la Cámara de Diputados de la reforma constitucional de telecomunicaciones 2013, Diario de los Debates de la Cámara de Diputados, Legislatura LXII, Segundo Periodo de Sesiones Ordinarias del Primer año, 21 de marzo de 2013, Volumen IV, Sesión 17, pp. 349-424, (Nov. 12, 2014, 11:20 AM) http://cronica.diputados.gob.mx/PDF/62/2013/mar/130321-4.pdf (Mex.); Presentación y votación en el Pleno de la Cámara de Senadores de la reforma constitucional de telecomunicaciones 2013, Diario de los Debates de la Cámara de Senadores, Legislatura LXII, Año I, Segundo Periodo Ordinario, 19 de abril de 2013, Diario núm. 27, pp. 28-562, (Nov. 12, 2014, 11.30 AM) http://www.senado.gob.mx/content/sp/dd/content/cale/diarios/62/1/ SPO/PDF-WEB/D27-19-ABRIL-2013.pdf (Mex.); Presentación, discusión y votación en el Pleno de la Cámara de Diputados de la reforma constitucional de telecomunicaciones 2013, Diario de los Debates de la Cámara de Diputados, Legislatura LXII, Segundo Periodo de Sesiones Ordinarias del Primer año, 25 de abril de 2013, Volumen III, pp. 276-306, (Nov. 12, 2014, 11.35 AM) http://cronica.diputados.gob.mx/PDF/62/2013/abr/130425-3.pdf (Mex.); Presentación y votación en el Pleno de la Cámara de Senadores de la reforma constitucional de telecomunicaciones 2013, Diario de los Debates de la Cámara de Senadores, Legislatura LXII, Año I, Segundo Periodo Ordinario, 30 de abril de 2013, Diario núm. 32, pp. 661-798 (Nov. 12, 2014, $11.40 \mathrm{AM}$ ) http://www.senado.gob.mx/content/sp/dd/content/cale/diarios/62/1/ SPO/PDF-WEB/D32-30-ABR-2013.pdf; Presentación, discusión y votación en el Pleno de la Cámara de Senadores de las leyes secundarias de telecomunicaciones 2014, Diario de los Debates de la Cámara de Senadores, Legislatura LXII, Año II, Tercer Periodo Extraordinario, 4 de julio de 2014, diario núm. 1, (Nov. 12, 2014, 11.45 AM) http://www.senado.gob.mx/ content/sp/dd/content/cale/diarios/62/2/TPE/PDF-WEB/TPE_D1_04_JUL_2014. pdf (Mex.); Presentación, discusión y votación en el Pleno de la Cámara de Diputados de las leyes secundarias de telecomunicaciones 2014, Diario de los Debates de la Cámara de Diputados, Legislatura LXII, Año II, Tercer Periodo Extraordinario, 8 de julio de 2014, Volumen I (pp. 19142) and Volumen II (pp. 143-224), (Nov. 12, 2014, 11.50 AM) http://cronica.diputados.gob. mx/PDF/62/2014/jul/140708-1.pdf__ http://cronica.diputados.gob.mx/PDF/62/2014/ jul/140708-2.pdf (Mex.). 
Why did these reforms fail to generate any real debate in Congress? One explanation is that the ruling PRI party had forged an alliance with smaller parties that gave it an overwhelming majority of votes. Another reason is Congress was involved in at least 3 major reforms (political-electoral, ${ }^{20}$ ener$\mathrm{gy}^{21}$ and telecommunications), ${ }^{22}$ each of which demanded full-time commitment. Can an ordinary individual assimilate such diverse topics within such a limited time frame? Since legislators often struggle to adequately understand just one area (e.g., energy), the idea of grasping all details necessary to formulate and decide on every amendment under consideration was clearly unrealistic. Thus, several major reforms were passed without due consideration.

\section{Telecommunications in the Constitution}

The Mexican Constitution was amended 9 times during $2013 ;^{23}$ one of these amendments affects the telecom sector. ${ }^{24}$ This section summarizes these

20 The political-electoral reform comprised the enactment of 3 new laws (Ley General de Partidos Políticos, Ley General de Instituciones y Procedimientos Electorales and Ley General en Materia de Delitos Electorales), and the amendment of 3 other laws (Ley General del Sistema de Medios de Impugnación en Materia Electoral, Ley Orgánica del Poder Judicial de la Federación, and Ley Federal de Responsabilidades Administrativas de los Servidores Públicos).

21 The energy reform comprised the enactment of 9 new laws (Ley de Petróleos Mexicanos, Ley de la Comisión Federal de Electricidad, Ley de Hidrocarburos, Ley de los Órganos Reguladores Coordinados en Materia Energética, Ley de la Agencia Nacional de Seguridad Industrial y Protección al Medio Ambiente del Sector Hidrocarburos, Ley de la Industria Eléctrica, Ley de Energía Geotérmica, Ley de Ingresos sobre Hidrocarburos, and Ley del Fondo Mexicano para la Estabilización y el Desarrollo) and the amendment of 12 other laws (Ley Federal de las Entidades Paraestatales, Ley de Adquisiciones, Arrendamientos y Servicios del Sector Público, Ley de Obras Públicas y Servicios Relacionados a las Mismas, Ley de Inversión Extranjera, Ley Minera, Ley de Asociaciones Público Privadas, Ley Orgánica de la Administración Pública Federal, Ley de Aguas Nacionales, Ley Federal de Presupuesto y Responsabilidad Hacendaria, Ley General de Deuda Pública, Ley Federal de Derechos, and Ley de Coordinación Fiscal).

22 The telecommunications reform comprised the enactment of 2 new laws (Ley Federal de Telecomunicaciones y Radiodifusión and the Ley del Sistema Público de Radiodifusión del Estado Mexicano), and the amendment of 11 laws (Ley de Inversión Extranjera, Ley Federal del Derecho de Autor, Ley Federal de Responsabilidades Administrativas de los Servidores Públicos, Ley de Amparo, Ley del Sistema Nacional de Información Estadística y Geográfica, Ley Federal de Metrología y Normalización, Ley Orgánica del Administración Pública Federal, Código Penal Federal, Ley Federal de Transparencia y Acceso a la Información Pública Gubernamental, Ley de Asociaciones Público Privadas, and Ley Federal de Entidades Paraestatales).

23 Cámara de Diputados, Reformas Constitucionales en Orden Cronológico, (Aug. 20, 2014, 10:00 AM) http://www.diputados.gob.mx/LeyesBiblio/ref/cpeum_crono.htm (Mex.).

24 Decreto por el que se reforman y adicionan diversas disposiciones de los artículos $6^{\circ}$, $7^{\circ}, 27,28,73,78,94$ y 105 de la Constitución Política de los Estados Unidos Mexicanos, 
changes and discusses the constitutionality of the new Telecommunications and Broadcast Law (LFTR). ${ }^{25}$

The Mexican Constitution recognizes human rights, demarcates national territory, and establishes the Federal system, the government structure and its divisions. The Constitution has been used by legislators as an instrument of public policy under the assumption that if a new right for citizens is included in the Constitution, then it will become a reality. However, such assumption is not supported by Mexican history. For example, the right to education is in the Constitution since the beginning of the $20^{\text {th }}$ century, nonetheless, many Mexican children are still unable to enjoy their right to education. The same is applicable with the right to health, to a sound environment, to a dwelling, and so forth. Regarding the telecom reform, the same assumption was made in connection with the right to access information and communication technologies, telecom and broadcasting services, internet and broadband.

The telecom amendment was enacted to: (1) recognize a right to access information and communication technologies, broadcast, telecommunications, internet and broadband services; (2) recognize that media audience has rights, mandate Congress to establish them in the law and provide mechanisms to protect them; and (3) curb the dominance of big industry players like America Movil (Telmex and Telcel) and Televisa. In the case of Televisa its power is over public opinion formation and democracy, whereas America Movil's power impacts the economy and telecom service users insofar as they are able to set high prices for the services America Movil provides.

The amendment's mandate is to guarantee economic competition, content plurality and to encourage universal coverage, convergence, quality and, most importantly, user access. It granted the regulator with authority to sanction or even split up companies engaged, and to establish restrictions to avoid that preponderant carriers (preponderantes) abuse of their market power.

The amendment is very broad and includes the following:

- The right of access to information and communications technology, telecom, broadcast, broadband and Internet services.

- Telecom and broadcasting services ${ }^{26}$ are considered public services of general interest.

- Unlike the then existing telecom regulator (Cofetel), the Instituto $\mathrm{Fe}^{-}$ deral de Telecomunicaciones (IFT) is independent from the executive and legislative branches, and will function as the telecom sector's exclusive antitrust agency. The IFT also has several faculties regarding au-

[Decree by which several provisions of articles $6^{\circ}, 7^{\circ}, 27,28,73,78,94$ and 105 of the Political Constitution of the United Mexican States are amended or added], Diario Oficial de la Federación [D.O.], 11 de junio de 2013, (Mex.).

25 Ley Federal de Telecomunicaciones y Radiodifusión.

26 Broadcasting services are considered free-to-air radio and television, whereas telecommunications include all other electronic communications services. 
Esta revista forma parte del acervo de la Biblioteca Jurídica Virtual del Instituto de Investigaciones Jurídicas de la UNAM

dience rights and content (programming and advertisement) delivered through broadcast stations and telecom networks.

- The only legal challenge to a regulation, act or omission of the IFT is through a special judicial review (juicio de amparo indirecto) and injunctions are prohibited. ${ }^{27}$

- The creation of an independent public agency to provide broadcasting services in Mexico. ${ }^{28}$

- Licenses that may be granted for commercial, private, public or social use. "Social use" includes use by communities and indigenous peoples.

- The creation of specialized judges and courts in broadcasting, telecommunications and economic competition matter to provide more certainty in this highly litigated field.

- Creation of the figure of preponderant carrier (see section VII below).

- Compulsory and free retransmission obligations of free-to-air signals through pay TV (must carry) and programming offer by free-to-air TV carriers of their signals for pay TV operators so that they are able to comply with must carry obligations (must offer). ${ }^{29}$ The free of charge retransmission are not applicable for preponderant carriers.

- Increase of foreign ownership to $100 \%$ in telecom and $49 \%$ in broadcast (provided there is reciprocity in the investor's country of origin for broadcast licenses). ${ }^{30}$

\section{INDEPENDENT REGULATOR?}

Although the IFT was created as a constitutionally autonomous entity (órgano constitucional autónomo) ${ }^{31}$ the Mexican Department of State (Segob) ${ }^{32}$ re-

27 The juicio de amparo indirecto is a type of legal proceeding whereby the constitutionality and legality of acts of authority are challenged. Although not the same as a judicial review of the US legal system, the juicio de amparo could be deemed as equivalent to judicial review.

28 Sistema Público de Radiodifusión del Estado Mexicano.

29 Under must carry obligation, pay TV licensee must retransmit the free-to-air channels that are broadcasted in the same area of service. Must offer obligation is for the broadcaster that must provide the free-to-air channels to the pay TV licensees so that they include such channels in their TV guide.

30 Prior to the constitutional amendment, no foreign investment was allowed in the broadcasting sector; in telecom, there was a cap of $49 \%$. The only exception was cellular services, which had no foreign investment cap. See Alvarez, supra note 1, at 420.

31 This category is the maximum autonomy that the Mexican State grants to any public agency, and implies that the agency is not part of the Executive, neither it is from the Legislative, nor from the Judicial branch. Filiberto Valentín Ugalde Calderón, Órganos Constitucionales Autónomos, 29 Revista del Instituto de la Judicatura Federal 253 (Nov. 4, 2014, 2:00 PM) http://www.ijf.cjf.gob.mx/publicaciones/revista/29/Filiberto $\% 20$ Valent $\%$ C $3 \%$ ADn $\% 20$ Ugalde\%20Calderón.pdf (2010).

32 Secretaría de Gobernación. 
tained certain authority over audiovisual content and radio and television transmissions. The LFTR also recognized the authority of the Ministry of Communications ${ }^{33}$ to issue opinions regarding licenses that are granted, revoked, transferred or whose controlling party will change; and to the Ministry of Finance ${ }^{34}$ to issue opinions regarding payments to be received by the Mexican Treasury for telecom licenses. Do these faculties granted to executive agencies infringe upon the constitutional autonomy of the IFT?

In effect, the Senate report re-authorized Segob to oversee audiovisual content as it has since 1960, pursuant to the argument that the Constitution does not expressly confer such rights on the IFT. ${ }^{35}$ This line of reasoning is debatable for several reasons, as explained below.

The Mexican Constitution expressly grants the IFT the authority to regulate telecom and broadcasting services ${ }^{36}$. Unlike the Ministry of Communications or the Ministry of Finance, Segob is not given any specific faculties neither express nor impliedly. For this reason, there is no basis for Segob's authority regarding audiovisual content; and no evidence exists of the legislature's intent to grant that authority in the 2013 amendment process.

Since the nature of radio and television depends on audiovisual content, any authority granted to the IFT regulator for telecom and broadcasting matters must include electronically transmitted content, as this is within its scope by nature.

Content transmitted via radio and TV involve the right of freedom of expression $^{37}$, as they are intertwined with the right to information. In a democracy, the regulation of radio and TV content should not be given to the same public agency that regulates internal affairs, public safety, national security and intelligence services (as is the case with Segob). Prior to Mexico's democratic transition, it was arguably understandable that Segob regulated these matters. In 1960, Mexico's executive branch did not respect human rights in

33 Secretaría de Comunicaciones y Transportes.

34 Secretaría de Hacienda y Crédito Público.

35 Senado de la República, Dictamen de las comisiones unidas de Comunicaciones y Transportes, Radio, Televisión y Cinematografia, y de Estudios Legislativos, con proyecto de Decreto por el que se expiden la Ley Federal de Telecomunicaciones y Radiodifusión, y la Ley del Sistema Público de Radiodifusión del Estado Mexicano; y se reforman, adicionan y derogan diversas disposiciones en material de telecomunicaciones y radiodifusion, [Report of the united commissions of Communications and Transportation, Radio, Television and Cinema, and of Legislative Studies, with a draft Decree by which the Federal Telecommunication and Broadcasting Law and the Public Broadcasting System of the Mexican State are enacted, and by which several telecommunication and broadcasting provisions are amended, added and repealed], pp. 179-197 and 255, 1 de julio de 2014 (Mex.).

36 Constitución Política de los Estados Unidos Mexicanos [Const.], as amended, Diario Oficial de la Federación [D.O.], 5 de febrero de 1917 (Mex.), article 28.

37 Libertad de EXPREsión. La RAdIOdifusión ES Un MEdio TECNOLÓGICO PARA EJERCER ESE Derecho, Primera Sala de la Suprema Corte de Justicia de la Nación [S.C.J.N.] [Supreme Court], Semanario Judicial de la Federación y su Gaceta, Novena Época, Libro IX, Junio de 2012, Tomo 1, Registro 160070, Tesis 1a. XIX/2012, p. 262 (Mex.). 
Esta revista forma parte del acervo de la Biblioteca Jurídica Virtual del Instituto de Investigaciones Jurídicas de la UNAM

general; freedom of expression was no exception and the right to information was not recognized as human right. ${ }^{38}$ In the $21^{\text {st }}$ century, however, there is no justifiable reason for Segob to have continued with regulatory authority over audiovisual content.

The Human Rights Commission of Mexico City made the following argument before the Senate:

...the autonomy and faculties of the IFT help guarantee the impartial oversight of content, giving legitimacy to this work and avoiding as much as possible the involvement of other entities in regulating media expression. From a human rights perspective, losing this autonomy and impartiality by transferring these faculties to another agency may produce illegitimate controls and restrictions on freedom of expression, in accordance with international standards of freedom of expression, in effect sending a chilling message regarding free media expression. ${ }^{39}$

\section{Media and Plurality}

Mexico's free-to-air TV has long been dominated by two media conglomerates: Televisa and TV Azteca. In free-to-air TV, they directly or indirectly hold $95 \%$ of commercial licenses, $90 \%$ of audience share, and $99 \%$ of advertising revenue. ${ }^{40}$ Federal and state governments own and operate certain freeto-air TV channels, and none of them have enacted regulation for assuring

38 Ernesto Villanueva, Derecho de la Información, 63-65 (Miguel Ángel Porrúa and Cámara de Diputados) (México, 2006).

39 “...la autonomía y facultades del IFT son garantías para que la supervision de los contenidos se lleve a cabo con plena imparcialidad, dando legitimidad a este trabajo y evitando lo más que se pueda la intervención de otros poderes en el ejercicio de la libertad de expression en medios de comunicación. Perder esta autonomía e imparcialidad al trasladar estas funciones a otro órgano, desde un enfoque de derechos humanos, podría devenir en controles y limitaciones ilegítimas de acuerdo a los estándares internacionales de libertad de expression, en mecanismos de censura o, incluso, en un mensaje amedrentador para la libertad de expression en medios de comunicación" [author's translation], Comisión de Derechos Humanos del Distrito Federal, Análisis sobre Iniciativa de Ley de Telecomunicaciones [Analysis of the Telecommunications Law Bill], CDHDF/OE/P/0141/2014, 11 de abril de 2014 (Nov. 7, 2013 1:17 PM), http://www.senado.gob.mx/comisiones/comunicaciones_transportes/docs/ Telecom/Posicionamiento_CDHDF.pdf (Mex.).

40 Instituto Federal de Telecomunicaciones, Acuerdo mediante el cual el Pleno del Instituto Federal de Telecomunicaciones determina el valor mínimo de referencia, a que se refiere el numeral 4.1.3.5 de las Bases de Licitación Pública para concesionar el uso, aprovechamiento y explotación comercial de canales de transmisión para la prestación del servicio público de televisión radiodifundida digital, a efecto de formar dos cadenas nacionales en los Estados Unidos Mexicanos (Licitación No. IFT-1), Pleno, XI Sesión Extraordinaria, P/IFT/EXT/150414/90, p. 22, (Nov. 11, 2014, 13:05 PM), http://www.ift.org.mx/iftweb/ wp-content/uploads/2014/04/IFT_EXT_150414_90_valor_minimo.pdf, 15 de abril de 2014 (Mex.). 
editorial independence (e.g. fix term for the general director, minimum annual budget). There are few social media channels such as community radio or indigenous radio stations. For this reason, broadcast media plurality is a major challenge for true democracy in Mexico. Although internet and broadband access could be deemed as alternative media to access to information, they are still not sufficiently widespread for the population in general to be considered an alternative news media.

Under the new amendment, telecom and broadcasting licenses shall be granted for social use, including grants to certain communities (e.g. non-profit organization for women's rights, San Juan Ixcaquixtla community) and indigenous groups (e.g. mazateco people living in Puebla, yaqui people living in Sonora). This would go a long way toward encouraging plurality in Mexico. ${ }^{41}$ This said, the LFTR includes several provisions that negatively (and unjustifiably) discriminate against communities and indigenous people, as evidenced below:

- Any license for commercial or private use of the spectrum may be granted for up to 20 years. For social use, however, the maximum is 15 years. ${ }^{42}$ Nothing exists in the legislative record to indicate any intent to differentiate between commercial/private and social/public.

- The solicitation and acquisition process for a spectrum license for social use is subject to the IFT's discretion. The article of the law that expressly refers to the information that the applicants must provide to the regulator, is not an exhaustive list as it refers to a minimum of information ("at least provide") and not a maximum. ${ }^{43}$ Note that a similar provision was held unconstitutional by the Mexican Supreme Court in a case that also dealt with broadcast spectrum licenses for not-for-profit entities. $^{44}$

41 Special Rapporteur for Freedom of Expression of the Inter-American Commission on Human Rights, Freedom of Expression Standards for Free and Inclusive Broadcasting, paragraphs 26 to 37 (2010).

42 Ley Federal de Telecomunicaciones y Radiodifusión [L.F.T.R.] [Telecommunications and Broadcasting Law], articles 75 and 83, Diario Oficial de la Federación [D.O.], 14 de julio de 2014 (Mex.).

43 Ley Federal de Telecomunicaciones y Radiodifusión [L.F.T.R.] [Telecommunications and Broadcasting Law], article 85, Diario Oficial de la Federación [D.O.], 14 de julio de 2014 (Mex.).

44 Suprema Corte de Justicia de la Nación [S.C.J.N] [Supreme Court], Sentencia relativa a la Acción de Inconstitucionalidad 26/2006 promovida por Senadores integrantes de la Quincuagésima Novena Legislatura del Congreso de la Unión, en contra del propio Congreso y del Presidente Constitucional de los Estados Unidos Mexicanos, así como los votos formulados por el señor Ministro Genaro David Góngora Pimentel, Pleno, Diario Oficial de la Federación [D.O.], 20 de agosto de 2007 (Mex.).Acción de Inconstitucionalidad 26/2006 resuelta por la Suprema Corte de Justicia de la Nación, publicada en el Diario Oficial de la Federación el 20 de agosto de 2007. 
- Each year, the IFT must publish a spectrum program whereby it provides information of which frequencies will be given in public auction or which ones will be granted for social or public use. Also, IFT must enact compulsory guidelines for applicants. ${ }^{45}$ No parameters currently exist to limit the nature of these guidelines.

- The IFT retains complete discretion to grant or deny a spectrum license for social use ${ }^{46}$ whereas the grant of commercial and private licenses are far more predictable. The Human Rights Commission of Mexico City, civil organizations and prominent academics have pointed out the unfairness of imposing stricter requirements for social use than for commercial use. ${ }^{47}$

- Social use licensees are prohibited from receiving advertising income, ${ }^{48}$ which runs counter to the Freedom of Expression Standards for Free and Inclusive Broadcasting. ${ }^{49}$ The latter expressly states that "legal provisions regulating community broadcasting must recognize the special nature of these media and contain, as a minimum, the following elements: (a) simple procedures for obtaining licenses; (b) no demand of severe technological requirements that would prevent them, in practice, from even being able to file a request for space with the State; and (c) the possibility of using advertising to finance their operations...". ${ }^{50}$

- The Supreme Court also ruled that the Mexican government had no right to prevent community media (e.g. radio or TV station owned and operated by the people of a local community) from receiving advertising income from public entities. ${ }^{51}$ The Human Rights Commission of Mexico City believes that social media restrictions "...limit the possi-

45 Ley Federal de Telecomunicaciones y Radiodifusión [L.F.T.R.] [Telecommunications and Broadcasting Law], article 90, Diario Oficial de la Federación [D.O.], 14 de julio de 2014 (Mex.).

46 Ley Federal de Telecomunicaciones y Radiodifusión [L.F.T.R.] [Telecommunications and Broadcasting Law], article 85, Diario Oficial de la Federación [D.O.], 14 de julio de 2014 (Mex.).

47 Comisión de Derechos Humanos del Distrito Federal, Análisis sobre Iniciativa de Ley de Telecomunicaciones [Analysis of the Telecommunications Law Bill], CDHDF/ OE/P/0141/2014, 11 de abril de 2014, p. 6 (Nov. 7, 2013 1:17 PM), http://www.senado. gob.mx/comisiones/comunicaciones_transportes/docs/Telecom/Posicionamiento_CDHDF. pdf (Mex.).

48 Ley Federal de Telecomunicaciones y Radiodifusión [L.F.T.R.] [Telecommunications and Broadcasting Law], article 89 section III, Diario Oficial de la Federación [D.O.], 14 de julio de 2014 (Mex.).

49 Special Rapporteur for Freedom of Expression of the Inter-American Commission on Human Rights, Freedom of Expression Standards for Free and Inclusive Broadcasting, 2010 (Nov. 12, 2014, 6:15 PM) http://bit.ly/XGOb5i.

50 See $I b$. number 101.

51 Suprema Corte de Justicia de la Nación [S.C.J.N] [Supreme Court], Sentencia definitiva del Amparo en Revisión 531/2011, Primera Sala, 24 de agosto de 2011. 
bility of financial autonomy and independence, as these organizations are prohibited from receiving income from advertisements of public entities...". 52

- Under the LFTR, the only exception for a community media station to receive income from advertisement is when this is from public agencies, but such income is restricted to the equivalent of $6 \%$ of transmission time for TV and $14 \%$ for radio. ${ }^{53}$ In addition, public agencies are prohibited from using over $1 \%$ of their advertising budget for these types of social use licenses..$^{54}$

The debate over the prohibition of advertising revenues by social use licensees must be viewed in relation to the National Broadcast Industry Chamber (CIRT) ${ }^{55}$ The CIRT has publicly stated on numerous occasions that neither public media nor social media should be allowed to receive advertising income as this would amount to "unfair competition". ${ }^{56}$ The "unfair competition" argument is based on the fact that arguably the commercial media do not receive any government subsidies, that advertisement generates income and a not-for-profit organization must not receive such income as that would be equivalent to perceiving earnings. Such unfair competition, however, makes no sense in light of the fact that social media do not compete with commercial media, and receiving income is not the same as having earnings or pursuing a commercial purpose. ${ }^{57}$

- The IFT may grant spectrum licenses for any type of use (commercial, private, public or social) at any broadcast FM or AM radio bands with

52 “...limita las posibilidades de autonomía financiera de estos medios y su posibilidad de ser independientes, en tanto les impide obtener ingresos por publicidad privada..." [author's translation] Comisión de Derechos Humanos del Distrito Federal, Análisis sobre Iniciativa de Ley de Telecomunicaciones [Analysis of the Telecommunications Law Bill], CDHDF/ OE/P/0141/2014, 11 de abril de 2014, p. 5 (Nov. 7, 2013 1:17 PM), http://www.senado. gob.mx/comisiones/comunicaciones_transportes/docs/Telecom/Posicionamiento_CDHDF. pdf (Mex.).

53 Ley Federal de Telecomunicaciones y Radiodifusión [L.F.T.R.] [Telecommunications and Broadcasting Law], article 237 section III, Diario Oficial de la Federación [D.O.], 14 de julio de 2014 (Mex.).

54 Ley Federal de Telecomunicaciones y Radiodifusión [L.F.T.R.] [Telecommunications and Broadcasting Law], article 89 section VII, Diario Oficial de la Federación [D.O.], 14 de julio de 2014 (Mex.).

55 Cámara Nacional de la Industria de Radio y Televisión.

56 Cámara Nacional de la Industria de Radio y Televisión (CIRT), Comunicado 8/2014, (Nov. 9, 2014, 11:18 AM) http://www.cirt.com.mx/portal/index.php/comunicacion/prensa / 1034-la-cirt-advierte-riesgos-por-competencia-desleal (Mex).

57 Clara Luz Álvarez, CIRT, ¿falso discurso?, El Financiero, 2 de junio de 2014 (Nov. 12, 2014, 6.20 PM), http://telecomysociedad.blogspot.mx/2014/07/cirt-falso-discurso-publicado-2de.html. 
one sole exception: licenses for communities or indigenous people. In that case, the IFT may only grant licenses on the extended mediumwave broadcast band, commonly known as the AM expanded band, or the upper frequencies of the FM band.$^{58}$ The problem, however, is that broadcast quality at these frequency allocations are inferior. In effect, this amounts to a per se unjustifiable discrimination against communities and indigenous people.

- Social use licenses for indigenous people are defined as those utilized to promote, develop and preserve indigenous languages and culture. ${ }^{59}$ In this way, the IFT may deny a license if it fails to fulfill this purpose, as well as those intended for political propaganda. In other words an indigenous community has limited rights to obtain a licenses for purposes that other ordinary citizens could apply for. This could amount to a discrimination and a restriction to freedom of expression of indigenous people. Moreover, article 2 of the Mexican Constitution mandates an affirmative action to promote indigenous media, whereas the LFTR establishes restrictions without reason and against the interests of indigenous people.

\section{Audience and User Rights}

Audience rights are related with content (programs and advertisement) delivered by telecom network or broadcast stations, whereas users rights are referred to those rights of a person as a user of telecom services (e.g. telephony, mobile phone, internet access). For the first time in Mexico, the Constitution acknowledges audience and users rights, and mandates that the law must provide mechanisms for protecting them. The Constitution refers also that there must be a balance between programming and advertisement, in other words, that there must be a maximum time allowed for advertisement.

Audience rights. Although the LFTR was enacted in 2014, it was based almost entirely on $20^{\text {th }}$ century concepts, e.g., audience rights are considered only in relation to broadcasting. ${ }^{60}$ No reference is made to other digital media platforms such as mobile TV, IPTV or on-demand internet services (e.g. Netflix).

58 Ley Federal de Telecomunicaciones y Radiodifusión [L.F.T.R.] [Telecommunications and Broadcasting Law], article 90, Diario Oficial de la Federación [D.O.], 14 de julio de 2014 (Mex.).

59 Ley Federal de Telecomunicaciones y Radiodifusión [L.F.T.R.] [Telecommunications and Broadcasting Law], article 67 section IV, Diario Oficial de la Federación [D.O.], 14 de julio de 2014 (Mex.).

60 Ley Federal de Telecomunicaciones y Radiodifusión [L.F.T.R.] [Telecommunications and Broadcasting Law], article 256, Diario Oficial de la Federación [D.O.], 14 de julio de 2014 (Mex.). 
The LFTR requires that all broadcasters maintain a code of ethics, and an ombudsperson established to defend audience rights. Anyone who considers radio or TV content to violate an audience right may file a claim before the channel's ombudsperson, who will review the claim and issue a ruling. ${ }^{61}$

The process for defending audience rights gives the appearance of an ordinary self-regulation procedure through an ombudsperson. ${ }^{62}$ However, under the LFTR there is no remedy if the licensee fails to comply with the ombudsperson's recommendation; nor is there any sanction for violating audience rights through content broadcast or pay TV transmissions. During the process at the Senate, the ombudspersons of broadcasting stations in Mexico issued a public declaration against the LFTR draft because, in their opinion "...audience rights may become meaningless, as compliance is completely subject to the discretion of both licensee and ombudsperson". ${ }^{63}$

Advertising. The Broadcast Act of 1960 (no longer in effect) established that advertising by TV broadcasters could not exceed $18 \%$ of the total transmission time; radio broadcasters were limited to $40 \% .{ }^{64}$ It is important to realize that in 1960, broadcasting stations transmitted for less than 24 hours per day. In 2006 an amendment to the Broadcast Act of 1960 (also known as Ley Televisa) granted broadcasters the right to increase advertising as a percentage of total broadcast time an additional $5 \%$ if they dedicate at least $20 \%$ of programming to independent national productions. ${ }^{65}$

Mexico had the chance to update its legislation in at least two significant ways: (1) ensure compliance with the constitutional mandate to balance advertising and programming; ${ }^{66}$ and (2) adapt to the 21 st century reality that

${ }^{61}$ Ley Federal de Telecomunicaciones y Radiodifusión [L.F.T.R.] [Telecommunications and Broadcasting Law], articles 259 and 261, Diario Oficial de la Federación [D.O.], 14 de julio de 2014 (Mex.).

62 See Ernesto Villanueva, La defensoría de la audiencia 49-64 (Instituto de Investigaciones Jurídicas de la UNAM and Radio Educación, Mexico) (2012).

63 See Francisco Prieto et al., El dictamen y los derechos de las audiencias. Posicionamiento de las Defensorías, 3 de julio de 2014 (Aug. 23, 2014, 9:15 AM) http://gabrielsosaplata.com/2014/07/03/el-dictamen-y-los-derechos-de-las-audienciasposicionamiento-de-las-defensorias/ [Translation by the author].

64 Reglamento de la Ley Federal de Radio y Televisión, en materia de Concesiones, Permisos y Contenido de las Transmisiones de Radio y Televisión [R.L.F.R.T.] [Regulations of the Broadcast Law of 1960, governing licenses, permits and broadcasting content], article 40, Diario Oficial de la Federación [D.O.], 10 de octubre de 2002 (Mex.).

65 Ley Federal de Radio y Televisión [L.F.R.T.] [Broadcast Law], as amended and nowadays repealed, article 72-A, Diario Oficial de la Federación [D.O.], 19 de enero de 1960 (Mex.).

66 Decreto por el que se reforman y adicionan diversas disposiciones de los artículos $6^{\circ}$, $7^{\circ}, 27,28,73,78,94$ y 105 de la Constitución Política de los Estados Unidos Mexicanos, [Decree by which several provisions of articles $6^{\circ}, 7^{\circ}, 27,28,73,78,94$ and 105 of the Political Constitution of the United Mexican States are amended or added], Diario Oficial de la Federación [D.O.], 11 de junio de 2013, (Mex.), article Eleventh transitory. 
most stations already transmit 24 hours a day and that the maximum amount of advertising must be computed per hour in order to prevent that advertisements at prime time could be of half the time of the programming, for example. Both the European Union ${ }^{67}$ and Argentina ${ }^{68}$ limit advertising to only 12 minutes per hour.

The above notwithstanding, the LFTR reused the same provisions of the Broadcasting Act of 1960. Neither the bill itself, ${ }^{69}$ nor the Senate reports ${ }^{70}$ nor the Chamber of Deputies reports ${ }^{71}$ went beyond out-of-date provisions, nor compared them with regulations in other countries.

TV broadcasters may thus transmit more advertising during prime time and less during off-peak hours. For example, in prime time a station may decide to transmit $50 \%$ of advertising per hour, and at 3 am only $1 \%$. The audience's constitutional right during prime time would in fact be infringed, although the law would not be violated.

The LFTR includes another provision that increases the audience exposure to more advertisements without a reasonable cause: if a broadcaster includes at least $20 \%$ of national production ${ }^{72}$ as part of its programming,

67 European Parliament and Council Directive 2010/13/EU (Audiovisual Media Services Directive), 2010 O.J. (L 95/1) article 23 section I (EG).

68 Ley 26.522 de Servicios de Comunicación Audiovisual [Audiovisual Communication Services Law 26.522], article 82 section b) (Arg.).

69 Presidente Enrique Peña Nieto, Iniciativa de Decreto por el que se expiden la Ley Federal de Telecomunicaciones y Radiodifusión, y la Ley del Sistema Público de Radiodifusión de México; y se reforman, adicionany derogan diversas disposiciones en materia de telecomunicaciones y radiodifusión, [Bill of the Decree by which the Federal Telecommunication and Broadcasting Law and the Public Broadcasting System of the Mexican State are enacted, and by which several telecommunication and broadcasting provisions are amended, added and repealed], 24 de marzo de 2014 (Mex.).

70 Senado de la República, Dictamen de las comisiones unidas de Comunicaciones y Transportes, Radio, Televisión y Cinematografia, y de Estudios Legislativos, con proyecto de Decreto por el que se expiden la Ley Federal de Telecomunicaciones y Radiodifusión, y la Ley del Sistema Público de Radiodifusión del Estado Mexicano; y se reforman, adicionan y derogan diversas disposiciones en material de telecomunicaciones y radiodifusion, [Report of the united commissions of Communications and Transportation, Radio, Television and Cinema, and of Legislative Studies, with a draft Decree by which the Federal Telecommunication and Broadcasting Law and the Public Broadcasting System of the Mexican State are enacted, and by which several telecommunication and broadcasting provisions are amended, added and repealed], 1 de julio de 2014 (Mex.).

71 Cámara de Diputados del Congreso de la Unión, Dictamen de las Comisiones Unidas de Comunicaciones, y de Radio y Televisión, con proyecto de decreto por el que se expiden la Ley Federal de Telecomunicaciones y Radiodifusión, y la Ley del Sistema Público de Radiodifusión del Estado Mexicano; y se reforman, adicionan y derogan diversas disposiciones en materia de telecomunicaciones y radiodifusión, [Report of the united commissions of Communications, and Broadcast, with a draft Decree by which the Federal Telecommunication and Broadcasting Law and the Public Broadcasting System of the Mexican State are enacted, and by which several telecommunication and broadcasting provisions are amended, added and repealed], 8 de julio de 2014 (Mex.).

72 National production is defined as content or programs created by a person with the majority of fundings or Mexican origin. Ley Federal de Telecomunicaciones y Radiodifusión 
then it may increase advertising as a percentage of total transmission time by an additional $2 \%$. This national production is different from the national independent production, adding both percentages then the maximum time of advertisement may be increased in 7\% more. ${ }^{73}$ The Mexican President's bill did not provide any arguments for such increases beside stating that such provision would foster national production.

The Senate reports stated:

In content-related matters, it is important to promote national production pursuant to the Constitution, for which reason this Decree allows commercial broadcasters who choose to use national and/or independent programming during at least $20 \%$ of their total programming time may increase the percentage of advertising time. This arrangement incentivizes licensees to use national programming and benefits national independent producers. ${ }^{74}$

The Chamber of Deputies did not provide any further argument regarding this matter, limiting discussion to wording and basically repeating the Senate's same arguments. ${ }^{75}$

[L.F.T.R.] [Telecommunications and Broadcasting Law], article 3 section XLVII, Diario Oficial de la Federación [D.O.], 14 de julio de 2014 (Mex.).

73 Ley Federal de Telecomunicaciones y Radiodifusión [L.F.T.R.] [Telecommunications and Broadcasting Law], article 247, Diario Oficial de la Federación [D.O.], 14 de julio de 2014 (Mex.).

74 "En materia de contenidos, también resulta relevante impulsar la producción nacional y atender lo señalado por la Constitución, por lo que el presente Proyecto de Decreto establece que los concesionarios de radiodifusión para uso comercial que cubran con producción nacional o producción nacional independiente, cuando menos un veinte por ciento de su programación, podrán incrementar el porcentaje de su tiempo de publicidad. El anterior esquema genera un incentivo para dichos concesionarios y a su vez beneficia a los productores nacionales independientes" [author's translation], Senado de la República, Dictamen de las comisiones unidas de Comunicaciones y Transportes, Radio, Televisión y Cinematografia, y de Estudios Legislativos, con proyecto de Decreto por el que se expiden la Ley Federal de Telecomunicaciones y Radiodifusión, y la Ley del Sistema Público de Radiodifusión del Estado Mexicano; y se reforman, adicionan y derogan diversas disposiciones en material de telecomunicaciones y radiodifusion [Report of the united commissions of Communications and Transportation, Radio, Television and Cinema, and of Legislative Studies, with a draft Decree by which the Federal Telecommunication and Broadcasting Law and the Public Broadcasting System of the Mexican State are enacted, and by which several telecommunication and broadcasting provisions are amended, added and repealed], p. 252, 1 de julio de 2014 (Mex.).

75 Cámara de Diputados del Congreso de la Unión, Dictamen de las Comisiones Unidas de Comunicaciones, y de Radio y Televisión, con proyecto de decreto por el que se expiden la Ley Federal de Telecomunicaciones y Radiodifusión, y la Ley del Sistema Público de Radiodifusión del Estado Mexicano; y se reforman, adicionan y derogan diversas disposiciones en materia de telecomunicaciones y radiodifusión [Report of the united commissions of Communications, and Broadcast, with a draft Decree by which the Federal Telecommunication and Broadcasting Law and the Public Broadcasting System of the Mexican State are enacted, and by which several telecommunication and broadcasting provisions are amended, added and repealed], pp. 121-122, 8 de julio de 2014 (Mex.). 
Broadcasters in other countries are legally obligated to include a certain percentage of national production but without a quid pro quo of increased advertising, as this would in fact affect the audience which must bear more advertisements and less programming. For example, member states of the European Union encourage TV broadcasters to allocate at least $10 \%$ of their transmission time to independent European productions; or invest at least $10 \%$ of their budget in independent European productions. ${ }^{76}$ In Colombia, TV broadcasters must comply with certain minimum national programming percentages on a quarterly basis that depends on the time of day. For example, Colombian national channels must include at least $70 \%$ of national production from 19 to 22.30 hours; between 10 and 19 hours and between 22:30 and 24 hours at least 50\% must be national production. On Saturdays, Sundays and holidays at least $50 \%$ of the programming must be national production from 19 to 22.30 hours. $^{77}$

Moreover, the LFTR defines national production as "content or programs generated by an individual or an entity financed primarily with resources of Mexican origin". ${ }^{78}$ This definition essentially permits that audiovisual or audio content may be produced abroad by a non-Mexican entity, with content relevant to another country with no reference to Mexico or its culture, but as long as such content is primarily financed by Mexican resources, then it complies with the LFTR definition and thus broadcasters may increase advertising time.

In contrast, Colombian legislation defines national production as: (1) programming which has been realized at all stages by Colombian artistic and technical personnel, with the participation of national actors in leading and secondary roles; and (2) foreign actors are allowed as long as they do not exceed $10 \%$ of leading roles, and are from nations that give the same or similar rights to Colombian actors. ${ }^{79}$

76 European Parliament and Council Directive 2010/13/EU (Audiovisual Media Services Directive), 2010 O.J. (L 95/1) article 17 (EG).

77 Ley 185 de 1995 por la cual se reglamenta el servicio de televisión y se formulan políticas para su desarrollo, se democratiza el acceso a éste, se conforma la Comisión Nacional de Televisión, se promueven la industria y actividades de televisión, se establecen normas para contratación de los servicios, se reestructuran [sic] entidades del sector y se dictan otras disposiciones en materia de telecomunicaciones [Law 185 of 1995 by which the television service is regulated and policies for its development are enacted, the access to television service is democratized, the National Television Commission is created, the television industry and activity is fostered, the norms to contract these services are established, the sector entities are restructured and the other provisions in telecommunications are enacted], as amended, (Col.).

78 Ley Federal de Telecomunicaciones y Radiodifusión [L.F.T.R.] [Telecommunications and Broadcasting Law], article 3 section XLVII, Diario Oficial de la Federación [D.O.], 14 de julio de 2014 (Mex.).

79 Ley 185 de 1995 por la cual se reglamenta el servicio de televisión y se formulan políticas para su desarrollo, se democratiza el acceso a éste, se conforma la Comisión Nacional de Televisión, se promueven la industria y actividades de televisión, se establecen normas para contratación de los servicios, se reestructuran [sic] entidades del sector y se dictan otras 
User rights. Politicians, legislators and media companies in favor of the LFTR claimed that it included several new rights for telecom users. These same rights, however, already existed in consumer regulation (NOM-184). ${ }^{80}$ Additionally, certain rights are better protected in the consumer regulation rather than in the new law. For example, when services are not rendered pursuant to the terms and conditions offered by the operator, consumer regulation entitles consumers to receive both a compensation equivalent to the time where services were not provided as they should, and at least a $20 \%$ bonus. ${ }^{81}$ The LFTR eliminated the minimum $20 \%$ bonus, hence the bonus will be unilaterally decided either by the telecommunications operator in its adhesion contract or by the authority and may be less than $20 \%{ }^{82}$

The consumer regulation cited above states that binding contracts may not include a clause allowing the telecom operator to unilaterally modify the terms and conditions entered into with a consumer, unless such modification implies a reduction of prices or an increase in services offered to the consumer at the same price. ${ }^{83}$ The LFTR allows the operator to include a clause that enables the operator to modify the terms and conditions subject to prior notice to the consumer. ${ }^{84}$ This LFTR provision fails to enhance telecom consumers' rights. In fact, it does the exact opposite insofar as the new LFTR allows operators to modify conditions without having to acquire prior consent.

\section{Public or Private Interests First?}

Although the telecom amendment was supposedly enacted to enhance democracy and increase access to culture, education, health and, in general, the

disposiciones en materia de telecomunicaciones [Law 185 of 1995 by which the television service is regulated and policies for its development are enacted, access to television service is democratized, the National Television Commission is created, television industry and activity is fostered, norms to contract these services are established, industrty entities are restructured and other telecom provisions are enacted], as amended, (Col.).

80 Norma Oficial Mexicana NOM-184-SCFI-2012 Prácticas comerciales-Elementos normativos para la comercialización y/o prestación de los servicios de telecomunicaciones cuando utilicen una red pública de telecomunicaciones [Official Mexican Norm NOM-184SCFI-2012 Commercial conduct-Provisions for commercialization and/or for providing telecommunication services when they involve the public telecommunication network] Diario Oficial de la Federación [D.O.] 24 de agosto de 2012 (Mex.).

${ }^{81} I$ Ib. Section 5.2.14.

82 Ley Federal de Telecomunicaciones y Radiodifusión [L.F.T.R.] [Telecommunications and Broadcasting Law], article 191 section XIII, Diario Oficial de la Federación [D.O.], 14 de julio de 2014 (Mex.).

83 Norma Oficial Mexicana NOM-184-SCFI-2012, supra note 70, at section 5.1.3, a).

84 Ley Federal de Telecomunicaciones y Radiodifusión [L.F.T.R.] [Telecommunications and Broadcasting Law], article 192 section I, Diario Oficial de la Federación [D.O.], 14 de julio de 2014 (Mex.). 
full exercise of human rights, the bill clearly reflects monopolists' battle to prioritize their own private interests over public welfare.

Preponderant carrier. The Constitution requires the IFT to determine preponderant carriers telecom and broadcast groups that hold more than $50 \%$ of national participation in such services based on the number of users, audience, network traffic or capacity, and impose special obligations in order to limit their market power. The only problem is that the Constitution refers to "sectors" in one paragraph and "services" in another one. For this reason, much LFTR-related debate was devoted to whether national participation should be based on sector (telecom and broadcast) or services (fixed telephony, mobile telephony, pay TV, internet access, radio and free-to-air TV).

Whether this calculation is based on sector or services produces very distinct results. Based on sector, for example, América Móvil (holding company of Telmex and Telcel) would be the preponderant carrier. Televisa, on the other hand, would not be preponderant, as it does not hold a majority share in radio broadcasting. If based on services, however, both América Móvil (fixed and mobile telephony and internet access) and Televisa (free-to-air TV and pay TV) would be deemed preponderant carriers.

The Senate and Deputy Chamber reports proposed an interpretation that preponderant would be by sector rather than by services. The LFTR simply copied the constitutional provision regarding preponderance ad verbatim and described the special obligations that could be imposed to the preponderant in telecom and to the preponderant in broadcast. Apparently one purpose of the telecom reform was to limit big corporate groups powers that affected competition, if so were the case, then the LFTR should have based its calculation on services (not by sector) to limit the market power as described in the paragraph above.

Before the LFTR was enacted, the IFT declared América Móvil as preponderant carrier in the telecom sector based on its number of users, ${ }^{85}$ and Grupo Televisa as preponderant carrier in the broadcast sector based on its audience. IFT stated that for determining Grupo Televisa as preponderant it would not consider free-to-air radio as it was a different market. ${ }^{86}$ Grupo

85 Instituto Federal de Telecomunicaciones, Resolución mediante la cual el Pleno del Instituto Federal de Telecomunicaciones determina al grupo de interés económico del que forman parte América Móvil, S.A.B. de C.V., Teléfonos de México, S.A.B. de C.V., Teléfonos del Noroeste, S.A. de C.V., Radiomóvil Dipsa, S.A.B. de C.V., Grupo Carso, S.A.B. de C.V., y Grupo Financiero Inbursa, S.A.B. de C.V., como agente económico preponderante en el sector de telecomunicaciones y le impone las medidas necesarias para evitar que se afecte la competencia y la libre concurrencia, Pleno, V Sesión Extraordinaria, P/IFT/EXT/060314/76 (March 5, 2015, 20:40 PM), www.ift.org.mx/iftweb/sector-de-telecomunicaciones/, 6 de marzo de 2014 (Mex.).

86 Instituto Federal de Telecomunicaciones, Resolución mediante la cual el Pleno del Instituto Federal de telecomunicaciones determina al grupo de interés económico del que forman parte Grupo Televisa S.A.B., Canales de Televisión Populares, S.A. de C.V., Radio Televisión, S.A. de C.V., Radiotelevisora de México Norte, S.A. de C.V., T.V. de los Mochis, S.A. de C.V., Teleimagen del Noroeste, S.A. de C.V., Televimex, S.A. de C.V., Televisión de Puebla, S.A. de C.V., Televisora de Mexicali, S.A. de C.V., Televisora de Navojoa, 
Televisa and its independent affiliates filed judicial reviews (amparos) against the preponderance, arguing inter-alia that free-to-air radio service is part of the broadcast sector and IFT had failed to include in its calculation the freeto-air radio audience.

Whether preponderance will ultimately be declared by sector or by service will depend on the criteria that the specialized tribunals adopt.

Cross-ownership. Cross-ownership of telecom and broadcasting licenses may be limited by the IFT pursuant to the Constitution. Such limits do not include any reference to other media (e.g. magazines, newspapers). "Limits to media cross-ownership are an instrument to prevent freedom of expression and the right to information from being affected by an over-concentration of media outlets in one corporate group. Media may be newspapers, magazines, radio and television stations, pay television and may even include the internet". ${ }^{87}$

The LFTR has a chapter for cross-ownership which over time will prove to be ineffective because the measures enacted do tackle the absence of plurality and limited access to diverse information through broadcast and telecom networks. The LFTR regards cross-ownership as a three-stage process:

$1^{\text {st }}$ stage: If there is limited access to plural information in certain markets and geographic areas, then the IFT may demand that the licensee of pay TV: (1) include certain news or public interest channels; and (2) include at least three channels with productions of mostly independent national programing which are independent from carriers. ${ }^{88}$ The main objection to this stage

S.A., Televisora de Occidente, S.A. de C.V., Televisora Peninsular, S.A. de C.V., Mario Enríquez Mayans Concha, Televisión La Paz, S.A., Televisión de la Frontera, S.A., Pedro Luis Fitzmaurice Meneses, Telemisión, S.A. de C.V., Comunicación del Sureste, S.A. de C.V., José de Fesús Partida Villanueva, Hilda Graciela Rivera Flores, Roberto Casimiro González Treviño, TV Diez Durango, S.A. de C.V., Televisora de Durango, S.A. de C.V., Corporación Tapatía de Televisión, S.A. de C.V., Televisión de Michoacán, S.A. de C.V., José Humberto y Loucille, Martinez Morales, Canal 13 de Michoacán, S.A. de C.V., Televisora XHBO, S.A. de C.V., TV Ocho, S.A. de C.V., Televisora Potosina, S.A. de C.V., TV de Culiacán, S.A. de C.V., Televisión del Pacífico, S.A. de C.V., Tele-Emisoras del Sureste, S.A. de C.V., Televisión de Tabasco, S.A. y Ramona Esparza González, como agente económico preponderante en el sector radiodifusión y le impone las medidas necesarias para evitar que se afecte la competencia y la libre concurrencia, Pleno, V Sesión Extraordinaria, P/IFT/EXT/060314/77 (March 5, 2015, 20:45 PM), www.ift.org.mx/iftweb/sector-deradiodifusion/, 6 de marzo de 2014 (Mex.).

87 "Los límites a la propiedad cruzada de medios son un instrumento para evitar que se afecte la libertad de expresión y el derecho a la información por la concentración en un grupo corporativo de diversos medios de comunicación. Éstos pueden ser periódicos, revistas, estaciones de radio y de televisión, televisión de paga e incluso se podría llegar a incluir el internet", [Author's translation], Clara Luz Álvarez, Propiedad cruzada de medios y pluralidad, Gaceta del IFT, Instituto Federal de Telecomunicaciones, Año 1, número 1, abrilmayo 2014, pp. 10-15 (June 30, 2014, 10:00 AM) http://www.ift.org.mx/iftweb/wp-content/ uploads/2014/04/Gaceta_IFT_Abril2014.pdf.

${ }^{88}$ Ley Federal de Telecomunicaciones y Radiodifusión [L.F.T.R.] [Telecommunications and Broadcasting Law], article 285, Diario Oficial de la Federación [D.O.], 14 de julio de 2014 (Mex.). 
is that in a country like Mexico, most people still primarily watch free-to-air TV. Only a minority of homes in Mexico have access to pay TV. For the sake of plurality, these measures should be applied to TV broadcasters rather than pay TV licensees.

$2^{\text {nd }}$ stage: In the event that a licensee fails to comply with the first stage, then the IFT may impose limits regarding (1) the number of broadcasting spectrum it may hold; (2) new spectrum broadcast licenses; and (3) crossownership of diverse media (broadcast/telecom) by one corporation in the same market and area. ${ }^{89}$

$3^{\text {rd }}$ stage: In the event that the first and second stages have failed, then the IFT may order divestment of the corporate group. ${ }^{90}$

Despite these cross-ownership rules, it will be difficult for the IFT to successfully implement each and every stage of this process because (a) the procedures are highly cumbersome; and (b) the legal tools are inadequate to achieve plurality.

Exemption to merger review. All telecom mergers that exceed a fixed amount must be authorized by the IFT. ${ }^{91}$ The IFT analyzes whether the merger will have adverse effects on competition, and may grant authorization, rejection or approval depending on compliance with certain conditions. The only exception to this review is set forth in the Antitrust Law of 2014, when the merger is (i) between agents that are not competitors, (ii) such agents are not from related markets, and (iii) it is notorious that there will be no negative impact on competition. ${ }^{92}$ Even in these exceptional cases Antitrust Law requires that the authority receives a filing prior to merger so that the authority analyses the case and confirms that the merger is one that notoriously does not affect competition.

During backdoor sessions in the Senate - outside public scrutiny - a provision was worked out to bypass the merger review. This became known as the Cablecom Clause because Televisa had announced in 2013 that it had acquired several debt instruments that could give it control of Cablecom, one of its pay TV competitors. ${ }^{93}$ Exemption would be permitted if (a) there is a preponderant; (b) a reduction of certain levels of the dominance index and

89 Ley Federal de Telecomunicaciones y Radiodifusión [L.F.T.R.] [Telecommunications and Broadcasting Law], article 286, Diario Oficial de la Federación [D.O.], 14 de julio de 2014 (Mex.).

90 Ley Federal de Telecomunicaciones y Radiodifusión [L.F.T.R.] [Telecommunications and Broadcasting Law], article 288, Diario Oficial de la Federación [D.O.], 14 de julio de 2014 (Mex.).

91 Ley Federal de Competencia Económica [L.F.C.E.] [Antitrust Law] articles 61 and 86, Diario Oficial de la Federación [D.O.] 23 de mayo de 2014 (Mex.).

92 Ley Federal de Competencia Económica [L.F.C.E.] [Antitrust Law] article 92, Diario Oficial de la Federación [D.O.] 23 de mayo de 2014 (Mex.).

93 Bolsa Mexicana de Valores, Evento Relevante 1 de agosto de 2013, Grupo Televisa S.A.B., (November 11, 2014, 5:50 PM) http://www.bmv.com.mx/eventore/eventore_473142_1.pdf. 
the Herfindahl index would take place with the merger in the relevant sector (either telecom or broadcast sector); and (c) the merger would not give over $20 \%$ market share in the relevant sector to the acquirer.

Any acquirer that would like to be benefitted by the Cablecom Clause must provide notice to the IFT for review after the merger took place. If this review determines that the merger would give the acquirer a dominant position or adversely affect competition, then the IFT must initiate a new investigation to gauge the acquirer's market position and adopt measures to minimize adverse effects to competition. ${ }^{94}$

The rationale for approving the Cablecom Clause was arguably to foster competition and develop feasible long run competitors. However, an exception to the Antitrust Law (prior review and approval of a merger) must have had a better reason other than a fast-track merger process with no review in advance by the regulator and no possibility of imposing conditions to the merger. Moreover, article 28 of the Constitution prohibits the concentrations and acts that affect consumer welfare due to lack of effective competition, and Cablecom Clause essentially allows any merger (even between competitors of the same market and the same service) without the analysis of the IFT. This deprives the regulator of its faculties to overview the telecommunications development under a competitive market.

The same day that the LFTR entered into force, Grupo Televisa announced that it had acquired $100 \%$ of Cablecom. ${ }^{95}$ The provision analyzed in this section prevented the IFT from rejecting such merger, and the IFT did not impose conditions on Televisa-Cablecom from the merger post-review. ${ }^{96}$ Note that prior to the existence of the Cablecom Clause, the mergers by Televisa of other pay TV companies in 2006 and 2007 were subject to several conditions that purported to diminish the risk of anticompetitive behavior. ${ }^{97}$ On January 2015, Grupo Televisa announced that it had acquired one of its

94 Decreto por el que se expiden la Ley Federal de Telecomunicaciones y Radiodifusión, y la Ley del Sistema Público de Radiodifusión del Estado Mexicano; y se reforman, adicionan y derogan diversas disposiciones en materia de telecomunicaciones y radiodifusión [Decree by which the Federal Telecommunication and Broadcasting Law and the Public Broadcasting System of the Mexican State are enacted, and by which several telecommunication and broadcasting provisions are amended, added and repealed], article 9th transitory, Diario Oficial de la Federación [D.O.], 14 de julio de 2014, edición vespertina (Mex.).

95 Bolsa Mexicana de Valores, Evento Relevante 14 de agosto de 2014, Grupo Televisa S.A.B., (November 11, 2014, 5:55 PM) http://www.bmv.com.mx/eventore/eventore_544884_1.pdf.

96 Instituto Federal de Telecomunicaciones, Acuerdo mediante el cual el Pleno del Instituto Federal de Telecomunicaciones emite resolución en el expediente UCE/AVC-001-2014, de conformidad con lo establecido en los párrafos primero a cuarto del artículo Noveno Transitorio de la Ley Federal de Telecomunicaciones y Radiodifusión, Pleno, XXXVI Sesión Extraordinaria, P/IFT/EXT/101214/27 (March 5, 2015, 20:45 PM), www.ift.org.mx/iftweb/sector-de-radiodifusion/, 6 de marzo de 2014 (Mex.).

97 Miguel Flores Bernés, Telecomunicaciones y Competencia Económica 102-105, (Novum, 2012). 
Esta revista forma parte del acervo de la Biblioteca Jurídica Virtual del Instituto de Investigaciones Jurídicas de la UNAM

major competitors in pay TV in Mexico, Cablevisión Red.$^{98}$ Grupo Televisa has already filed its notice before the IFT, and it most certainly be processed in the same terms as the Cablecom acquisition.

\section{Human Rights Concerns}

The initial bill presented by president Peña Nieto posed major threats to human rights, as pointed out by the Human Rights Commission of Mexico City ${ }^{99}$ Although several changes were made to minimize these transgressions, several provisions of the LFTR regarding data retention by telecom operators and geolocation could affect human rights of Mexican telecom users as the right to privacy, for example.

Data retention. The LFTR requires telecom carriers to retain certain data from users' communications for a period of 24 months. The data must be: communication type (voice, data, SMS, voice mail, call forwarding); originating and recipient points; and date, hour and length of each communication, among others. ${ }^{100}$ These transmissions contain information that are capable of revealing personal data, including political ideology, sexual preference and mental health problems, for example.

It is important to note that the European Court of Justice ruled on April 2014 that data retention by telecom carriers for investigation of grave crimes as set forth in the Data Retention Directive violated human rights because of infringement of the proportionality principle. ${ }^{101}$

Geolocation. Geolocation is used to identify the real-time location of a mobile device through carrier-held data. Although geolocation was already contemplated in Mexican law, ${ }^{102}$ its use was limited to: (1) investigations of serious crimes, e.g., organized crime, kidnapping, extortion, threats, and drug deal-

98 Bolsa Mexicana de Valores, Evento Relevante 8 de enero de 2015, Grupo Televisa S.A.B., (March 5, 2015, 9:00 PM) http://www.bmv.com.mx/eventore/eventore_569778_1.pdf.

99 Comisión de Derechos Humanos del Distrito Federal, Presidencia, Análisis sobre iniciativa de Ley de Telecomunicaciones, CDHDF/OE/P/0141/2014, April 11, 2014, http://www.senado. gob.mx/comisiones/comunicaciones_transportes/docs/Telecom/Posicionamiento_CDHDF. pdf (Date of consultation: August 21, 2014).

100 Ley Federal de Telecomunicaciones y Radiodifusión [L.F.T.R.] [Telecommunications and Broadcasting Law], article 190 section II, Diario Oficial de la Federación [D.O.], 14 de julio de 2014 (Mex.).

101 See European Union Court of Justice, Press release 54/14 of April 8, 2014 regarding the final judgement of C-293/12 y C-594/12 of Digital Rights Ireland and Seitlinger et al., (May 30, 2014, 7:30 PM) http://curia.europa.eu/jcms/upload/docs/application/pdf/201404/cp140054es.pdf.

102 Ley Federal de Telecomunicaciones (hoy abrogada) [L.F.T., now repealed] [Telecommunications Federa Law], article 40 bis, Diario Oficial de la Federación [D.O.], 7 de junio de 1995 (Mex.). 
ing; and (2) solicitations by Federal and State Attorney Generals or prosecutors with due authority. ${ }^{103}$

Under the bill introduced by Mr. Peña Nieto, geolocation data requests were permitted by "security authorities", which include the Investigation and National Security Center (CISEN), ${ }^{104}$ Federal Police, Defense Ministry and Naval Ministry. The bill permitted these agencies to request geolocation data to performrealize "intelligence services," 105 defined in the National Security Law as "knowledge obtained through the collection, processing, dissemination and use of information for national security purposes". ${ }^{106}$ Notably, the bill contains no reference to "grave crimes"; thus geolocation by "security authorities" could be justified by many reasons as collection of information even if the person has committed no crime, nor is he/she related to any criminal investigation or to a national security threat.

The Senate amended the bill to allow any "competent authority to request geolocation data pursuant to applicable law". ${ }^{107}$ Under the LFTR, a citizen would need to be a legal specialist to know which laws, under which circumstances and which authorities could request the telecommunication operators to provide information regarding the geolocation of an equipment. As an example, on February 2015 the federal Attorney General delegated the power to request geolocation data and communication data of telecom users on basically all the heads of units, which include those that persecute intellectual property infringements, tax related issues, environmental investigations, public servant illicit conducts, and so on. ${ }^{108}$ Those units do not investigate nor

103 Ley Federal de Telecomunicaciones (hoy abrogada) [L.F.T., now repealed] [Telecommunications Federa Law], article 40 bis, Diario Oficial de la Federación [D.O.], 7 de junio de 1995 (Mex.).

104 Centro de Investigación y Seguridad Nacional.

105 Presidente Enrique Peña Nieto, Iniciativa de Decreto por el que se expiden la Ley Federal de Telecomunicaciones y Radiodifusión, y la Ley del Sistema Público de Radiodifusión de México; y se reforman, adicionany derogan diversas disposiciones en materia de telecomunicaciones y radiodifusión, [Bill of the Decree by which the Federal Telecommunication and Broadcasting Law and the Public Broadcasting System of the Mexican State are enacted, and by which several telecommunication and broadcasting provisions are amended, added and repealed], article 189, 24 de marzo de 2014 (Mex.).

106 "Se entiende por inteligencia el conocimiento obtenido a partir de la recolección, procesamiento, diseminación y explotación de información, para la toma de decisiones en materia de Seguridad Nacional." [Author's translation] Ley de Seguridad Nacional [L.S.N.] [National Security Law], as amended, article 29, Diario Oficial de la Federación [D.O.], 31 de enero de 2005 (Mex.)

107 Ley Federal de Telecomunicaciones y Radiodifusión [L.F.T.R.] [Telecommunications and Broadcasting Law], article 190 section I, Diario Oficial de la Federación [D.O.], 14 de julio de 2014 (Mex.).

108 Procuraduría General de la República, Acuerdo A/018/15 por el que se delega en los servidores públicos que se indican, diversas facultades previstas en el Código Nacional de Procedimientos Penales [Decree A/018/15 by which several faculties set forth in the National 
Esta revista forma parte del acervo de la Biblioteca Jurídica Virtual del Instituto de Investigaciones Jurídicas de la UNAM

prosecute grave crimes, nor are they related with national security. Finally, the LFTR does not require prior judicial review, nor can requests be made to file claims against abusive use of this data.

\section{Positive Aspects}

The LFTR does include certain positive elements, including provisions for ICT accessibility by persons with disabilities in Mexico, and the elimination of long distance charges, as explained below.

ICT accessibility. Although Mexico is part of the Convention on the Rights of Persons with Disabilities, it had never enacted a single law or regulation related to ICT accessibility. President's bill of law initially presented to the Mexican Congress had only three lines on ICT accessibility, providing for subtitles in news programs for multiprogramming channels in digital TV. ${ }^{109}$

During the legislative process an initiative was introduced by disability rights activists demanding that Congress address ICT accessibility on the basis of human rights. ${ }^{110}$ This initiative was supported by several senators from different political parties, the Human Rights Commission of Mexico City, and diverse media. The LFTR included two chapters and several provisions in relation to ICT accessibility that serve as a starting point.

The most relevant include: ${ }^{111}$

Criminal Proceeding Code are delegated on the public servants referred to therein], articles First, Second and Third, Diario Oficial de la Federación [D.O.], 23 de febrero de 2015 (Mex.).

109 Presidente Enrique Peña Nieto, Iniciativa de Decreto por el que se expiden la Ley Federal de Telecomunicaciones y Radiodifusión, y la Ley del Sistema Público de Radiodifusión de México; y se reforman, adicionan y derogan diversas disposiciones en materia de telecomunicaciones y radiodifusión, [Bill of the Decree by which the Federal Telecommunication and Broadcasting Law and the Public Broadcasting System of the Mexican State are enacted, and by which several telecommunication and broadcasting provisions are amended, added and repealed], article 161 section II, 24 de marzo de 2014 (Mex.).

110 Clara Luz Álvarez and Katia D’Artigues, Exposición de motivos, propuesta de capitulo de accesibilidad a telecomunicaciones y radiodifusión por personas con discapacidad, presented to the Senado de la República (Mex.), 11 de abril de 2014 (Nov. 13, 2014, 4.15 PM) http://claraluzalvarez. org/wp-content/uploads/2014/11/Cap\%C3\%ADtulo-Ax-Pers-Discap-c-Exp-Motivos1 labril2014-final-www.pdf.

111 See Decreto por el que se expiden la Ley Federal de Telecomunicaciones y Radiodifusión, y la Ley del Sistema Público de Radiodifusión del Estado Mexicano; y se reforman, adicionan y derogan diversas disposiciones en materia de telecomunicaciones y radiodifusión [Decree by which the Federal Telecommunication and Broadcasting Law and the Public Broadcasting System of the Mexican State are enacted, and by which several telecommunication and broadcasting provisions are amended, added and repealed], articles 161 section II, 199 to 203, 257 and 258 of the LFTR, and $43^{\circ}$ and $44^{\circ}$ transitory, Diario Oficial de la Federación [D.O.], 14 de julio de 2014, edición vespertina (Mex.). 
- Pulbic agency web sites must comply with accessibility criteria and be updated as technology evolves.

- Subtitles and sign language must be included in a minimum of one news program with national coverage.

- Closed captions must be featured in all programs scheduled between 6 am and midnight by commercial free-to-air TV channels with coverage exceeding $50 \%$ of national territory. Federal agency channels must also include closed captions. ${ }^{112}$

- Telecom carriers and mobile virtual network operators (MVNOs) must offer accessible formats for persons with disabilities.

- Broadcasters must provide accessible means for individuals with disabilities to file complaints about programming violations before the ombudsperson.

- The programming guides must be in accessible formats through a telephone number or a website.

Free long distance calls. The LFTR prevents telecom carriers from charging for long distance calls within national territory starting from January 1, 2015. ${ }^{113}$ This provision was designed to benefit low-income users, provided that the telecom service packages of telecom operators that included free long distance calls for a given price, were unaffordable for an average citizen.

\section{Final Remarks}

Media convergence in the digital era has erased all distinctions between broadcasting and other forms of telecommunications. For this reason, the nation needs a single legal framework for all electronic networks with the following characteristics: (a) competition in telecommunications is as important as plurality; (b) protection of the public interest instead of giving privileges to private interests; (c) a direct relationship between the legal rationale for provisions and public interest objectives; (d) coherent laws; and (e) content through different technological platforms should be governed by another law. Telecommunication services are more than just technology; they are essential for full enjoyment of several human rights.

\footnotetext{
112 This obligation must be complied with by August 2017.

113 See Decreto por el que se expiden la Ley Federal de Telecomunicaciones y Radiodifusión, y la Ley del Sistema Público de Radiodifusión del Estado Mexicano; y se reforman, adicionan y derogan diversas disposiciones en materia de telecomunicaciones y radiodifusión, [Decree by which the Federal Telecommunication and Broadcasting Law and the Public Broadcasting System of the Mexican State are enacted, and by which several telecommunication and broadcasting provisions are amended, added and repealed], article 118 section $\mathrm{V}$ of the LFTR, and $25^{\circ}$ transitory, Diario Oficial de la Federación [D.O.], 14 de julio de 2014, edición vespertina (Mex.).
} 
Esta revista forma parte del acervo de la Biblioteca Jurídica Virtual del Instituto de Investigaciones Jurídicas de la UNAM

Although the reform had the potential to increase democracy and enhance living standards, the real public interest (e.g., user and audience rights) never played a key role. Instead, the debate revolved around balancing benefits and costs between the same media oligarchs. The absence of real debate and discussion in both the Senate and Chamber of Deputies reflects how far Mexico must still travel to attain real democracy.

In light of these inadequacies, perhaps we must rely on digital technology to curtail Mexican media oligopolies and inject real competition into the telecom sector. The IFT mandate - namely, to guarantee economic competition and content plurality, and to encourage universal coverage, convergence, quality and access - has yet to be fulfilled. 